\title{
Global correlation of long Quaternary fluvial sequences: a review of baseline knowledge and possible methods and criteria for establishing a database
}

\author{
D.R. Bridgland ${ }^{1} \&$ D. Maddy $^{2}$
}

1 Corresponding author; Department of Geography, University of Durham, Durham DH1

3LE. email contact: d.r.bridgland@durham.ac.uk

2 Department of Geography, University of Newcastle upon Tyne, Newcastle upon Tyne NE1 7RU

Manuscript received: August 2001; accepted: April 2002

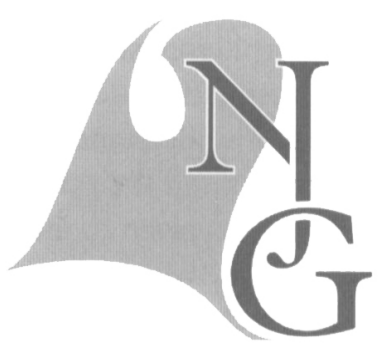

\begin{abstract}
Fluvial sequences, particularly major terrace staircases, represent potential archives of palaeoclimatic fluctuation during the Quaternary. Such sequences can span much if not all of the Quaternary and, provided that dating is possible, can serve as stratigraphical frameworks for correlation with evidence from other depositional environments. In particular, they can provide a terrestrial lithostratigraphical framework that can be correlated with the global marine oxygen isotope record. Fluvial lithostratigraphical frameworks also provide important contexts for records of faunal evolution and human occupation, the latter largely determined from the occurrence of artefacts in fluviatile sediments.

This paper announces a new project within the International Geological Correlation Programme, devoted to fluvial sequences (IGCP 449 'Global Correlation of Late Cenozoic fluvial deposits'). It attempts to summarize existing baseline knowledge at the outset of the project and outlines the proposed methods and criteria for establishing a database of fluvial sequences.
\end{abstract}

Keywords: fluvial deposits, river terraces, biostratigraphy, geochronology

\section{Introduction}

This paper derives from oral and poster presentations at the Fluvial Archives Group (FLAG) 2000 conference in Mainz, Germany. Both of these were intended to publicize a new International Geological Correlation Programme (IGCP) project, arising from a FLAG initiative, entitled 'Global Correlation of Late Cenozoic fluvial deposits' (IGCP 449). A further aim, continued in this paper, was to review existing knowledge, illustrate ways of disseminating information on long fluvial sequences and encourage participation in the project, which is due to run for five years from $2000 / 01$. This paper will represent a baseline statement, attempting to summarize, by way of examples, the existing knowledge onto which the IGCP project will build.
The IGCP project will be global, pooling information on long Quaternary fluviatile sequences from around the World. It is anticipated that important sequences can be recognized on all the continents, with the obvious exception of Antarctica. It is realised that little research will have been undertaken on some sequences, whereas the existence of others may as yet be undiscovered. It is hoped that the project can become the catalyst for new research designed to enhance the information available from all areas, especially those where study has thus far been at a minimal level.

Many of the best-known Pleistocene fluvial sequences are preserved in the form of terraces, recording the progressive incision of the river during the period concerned, activity that is believed to be a response to background uplift during the Quaternary 
(Bridgland, 1994, 2000; Van den Berg, 1994; Maddy, 1997; Antoine et al., 2000; Maddy \& Bridgland, 2000; Maddy et al., 2000; Westaway et al., 2002). Terrace sequences in some parts of the World (e.g. South Africa: Hattingh \& Rust, 1999), date back to the early Neogene or even the Palaeogene; the intention to include such sequences in their entirety is the rationale for the title of the project, although it is anticipated that the majority of the data will be from the Quaternary.

\section{Aims of IGCP 449}

This will be the first time that data on Late Cenozoic fluvial sequences from around the World have been compiled systematically and made available in an easily accessible form. Emphasis will be given to assembling data in a readily understandable format, through the use of summary diagrams and tables.

Specific objectives are as follows:

- Establishment of an agreed methodology and strategy for the study and recording of fluvial sequences;

- Compilation of a database of well-dated Late Cenozoic fluvial sequences from all parts of the World;

- Designation of the best of these as regional fluvial stratotypes, with which less-well dated sequences, partial sequences and sequences from other environments can be compared;

- Correlation of fluvial sequences with the global marine record, by whatever means possible and with emphasis on a multi-proxy approach;

- Dissemination of this information by publication, including on the internet, as well as through meetings to be held both as part of the IGCP project and more widely.

\section{Rationale: river sequences as important data archives}

IGCP 449 starts with the knowledge that an ample but at present poorly coordinated supply of data exists from the temperate latitudes of Eurasia, where typically river development during the late Cenozoic has led to the formation of staircases of terrace deposits (except in areas of subsidence). These staircases have been formed in response to climatic forcing (Bull, 1991; Bridgland, 1994, 2000), which has led to cyclic incision and aggradation in synchrony with glacial/interglacial cycles, superimposed, as already noted, upon a background of progressive uplift (Bridgland, 1994, 2000; Maddy, 1997; Antoine et al., 2000). In areas that have not experienced uplift, the climatic signal is still reflected by alternations of deposition and erosion (e.g. Vandenberghe, 1995), but rejuvenation and valley incision has not occurred (e.g. the lower Rhine). Staircases of large-scale aggradational river terraces are thus a notable feature of many valleys in the temperate latitudes, particularly in areas beyond the reach of the erosive and disruptive activities of Pleistocene ice sheets. The reconstruction of longitudinal profiles represents the main tool for correlation of often very fragmentary former floodplain remnants. Correlation can be undertaken additionally using sediment composition (e.g. clast lithologies, mineralogy, erratics), biostratigraphy and geochronology (see below). All the above methods can provide correlation between different reaches of a particular river; biostratigraphy and geochronology can provide correlation between widely separated river systems. For global correlation it is desirable to compare fluvial records with the global template for Neogene Quaternary climato-stratigraphy, the marine oxygen isotope record, optimally that from ODP 677 (Shackleton et al., 1990).

Fluvial sequences have the potential to provide frameworks for late Cenozoic stratigraphy on land. They benefit from a global distribution, being represented on all continents and across all climatic zones, with the exception of the polar regions and the driest deserts. Although the majority of readily accessible reported studies are from the temperate latitudes of Eurasia and North America, it is apparent that comparable data can be obtained from further afield: e.g. China, South America, India and Africa. An essential element of the IGCP project will be to integrate representative information from the full geographical range.

If river terraces can be dated, they can provide a means of gauging landscape change, since they record successive valley-floor levels. Terrace sequences can thus provide a framework for modelling fluvial incision as a part of landscape evolution (Veldkamp \& Van Dijke, 1998, 2000). It is thought that incision is a direct response to crustal uplift and therefore provides an approximate measure of the amount of that uplift (Van den Berg, 1994, 1996; Maddy, 1997; Maddy et al., 2000). Evidence from deformed fluvial sequences of the Mahi River, India (Jain et al., 1998) and rivers draining northwards from the Sudaten mountains, SW Poland (Krzyszkowski et al., 1998, 2000; Krzyszkowski \& Biernat, 1998), has provided records of fault movement in tectonically active areas. Such studies are of clear value to geophysical research.

Not all fluvial deposits form terraces; in subsiding sedimentary basins, grabens, aulacogens and in many 
continental shelf areas, thick piles of river sediments have accumulated during the Cenozoic. Study of these has not always been easy, generally relying on boreholes and geophysical techniques to determine the geometry and nature of buried and sometimes submerged (now offshore) sequences and channels (e.g. Ruegg, 1994; Yim, 1994; Bridgland \& D'Olier, 1995; Alekseev \& Drouchits, 1997; Veligrakis et al., 1999; Wingruth et al., 2000).

\section{Baseline position}

Table 1 summarizes the 'baseline' upon which IGCP 449 will build. It provides essential details of selected fluvial archives from around the World. The table gives an indication of the availability within each system of key evidence, such as palaeomagnetic polarity and other geochronological data, palaeontology, archaeology and the inputs from glaciations, marine transgressions and volcanic eruptions. The table indicates no more than presence/absence of selected criteria; many more lines of evidence will be explored by the project. The table is intended to be illustrative rather than exhaustive. The authors are keen to receive contributions in the form of updates and additions to the table, although it should be noted that the level of detail required for the IGCP 449 database will be considerably greater.

\section{Eurasia}

The inspiration for IGCP 449 comes from NW and central Europe, where there is a long history of research on Pleistocene fluvial sequences, providing ample data as a starting point for the project, beyond which little will be required other than translation into the chosen format, once this has been established (see below). Work on the terrace sequence and loessic overburden of the Svratka River valley, Brno, Czech
Republic (Kukla, 1975, 1977) provides an early exemplar for correlation with the climatic oscillations of the marine isotope sequence and for the presentation of data in a transverse staircase diagram (Fig. 1). The recognition of palaeosols within the loess provided the principal means for the relative dating of this sequence. Evidence of this type is also indicated in Table 1.

Beyond NW and central Europe, extensive Pleistocene fluviatile records are well documented from eastern and southern Europe, Asia Minor (see Middle East), Russia, the Himalayan foreland and China. Numerous rivers in eastern Europe have impressive Pleistocene records, although much of the published work is in languages other than English. Particularly notable are the sequences from rivers flowing from the north into the Black Sea, such as the Dniestr and Dniepr (Veklich et al., 1993; Markova \& Mihailescu, 1994; Matoshko et al., this volume). These sequences benefit from palaeomagnetic and biostratigraphical control; they record high-sea-level episodes in the form of evidence for marine transgressions of the Black Sea into the lower reaches of the rivers. To the north, glaciations have repeatedly injected erratic material into the upper reaches of these river systems. As well as biostratigraphical evidence from the fluvial and estuarine sediments, dating control for these Black Sea river sequences comes from loessic overburden with palaeosol horizons, as for the Svratka at Brno (Fig. 1). The use of palaeosol evidence from loessic overburden has proved valuable in areas of Eurasia as widely separated as the Somme, in northern France (Antoine, 1990; Antoine et al., 2000) and the Yellow River in China (Li, 1991; Porter et al., 1992; Table 1). In southern Europe, extensive terrace systems are documented from Iberia, where they are repositories for faunal and archaeological remains (Díaz del Olmo et al., 1989, 1993; Raposo, 1993; Raposo \& Santonja, 1995; Benito et al., 2000; Table 1).

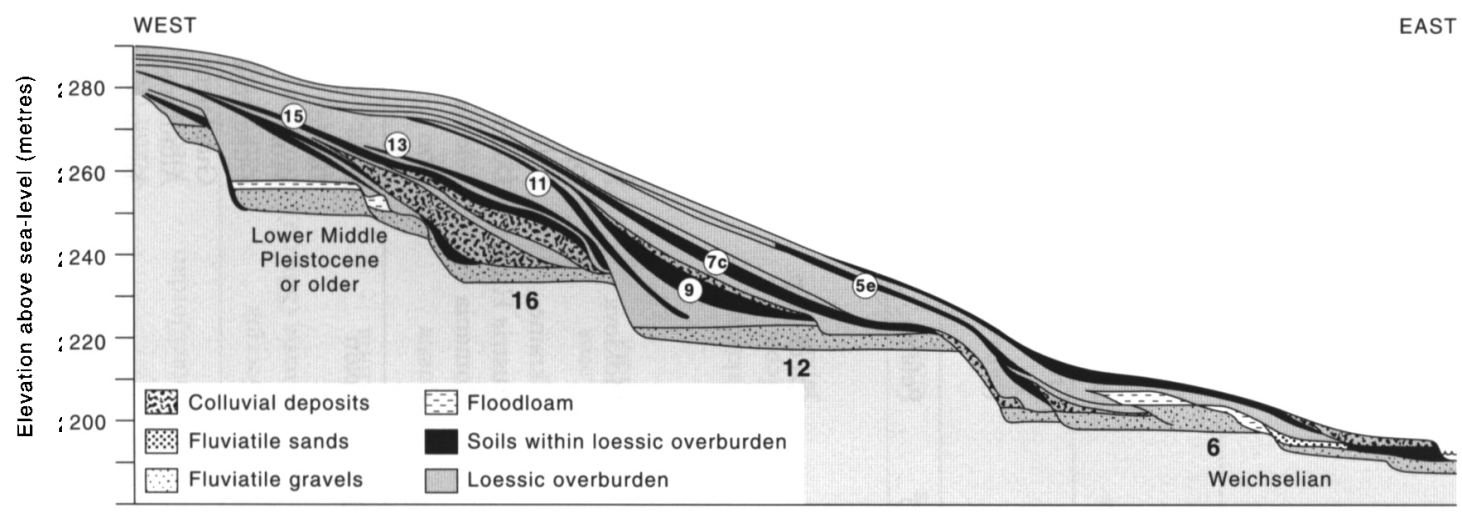

Fig. 1. Transverse section through the terraces of the River Svratka and their loessic overburden, with sequence of interglacial paleosols: The Red Hill, Brno, Czech Republic. Modified from Kukla $(1975,1977)$ in that suggested ages of fluviatile gravels and soils are given, using oxygen isotope stage notation where possible. 


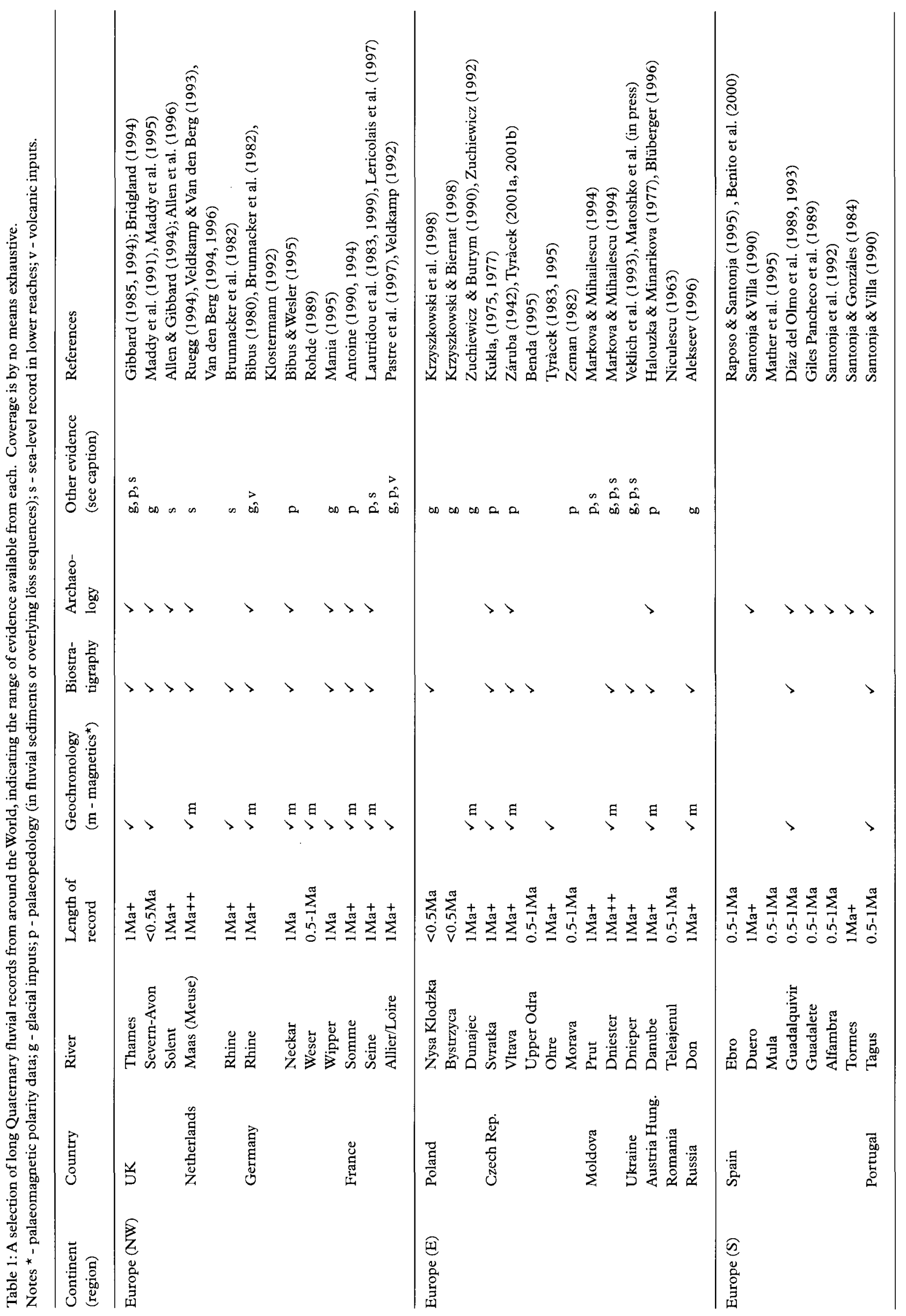



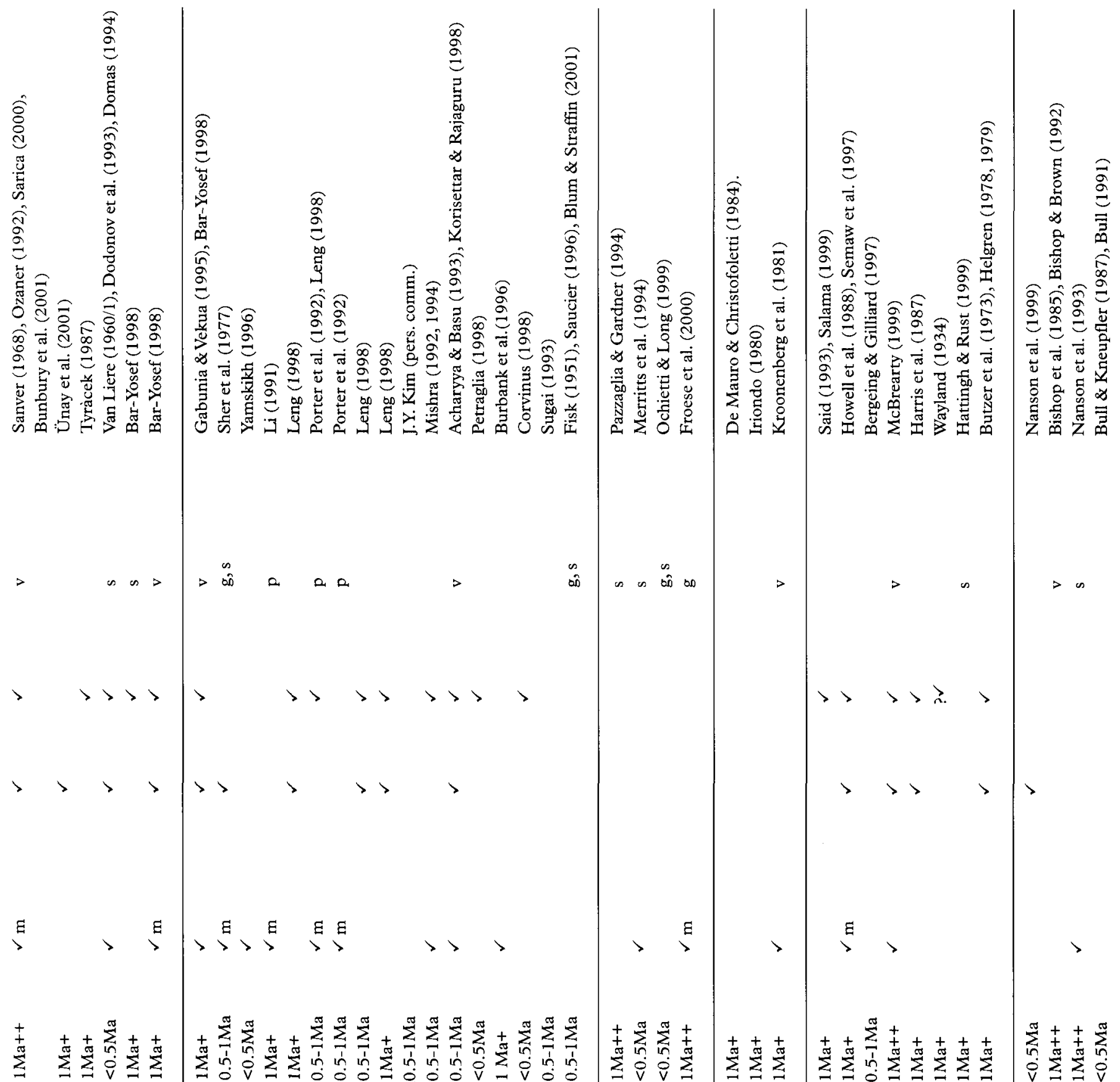

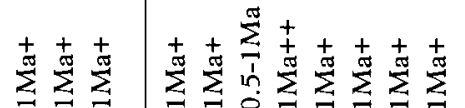

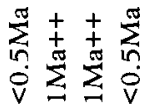

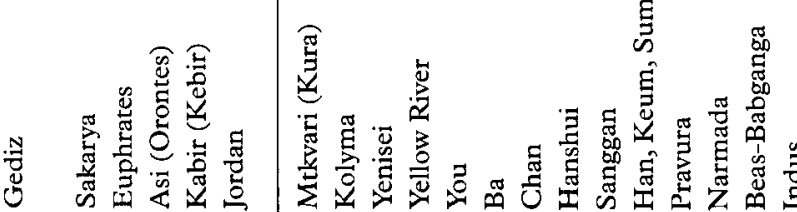

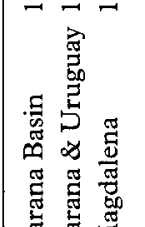

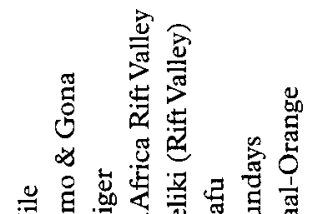

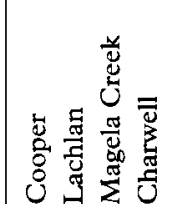

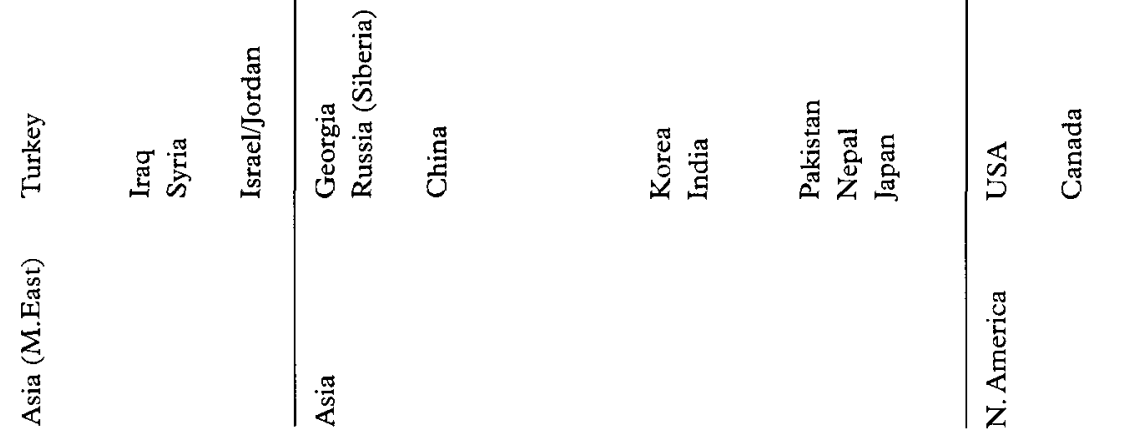

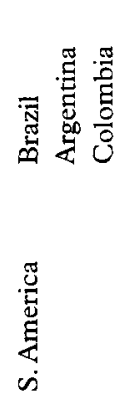
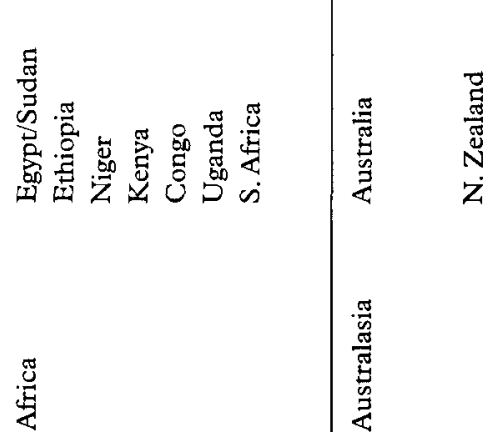
Again, it is anticipated that IGCP 449 will lead to the wider dissemination of these data.

\section{North America}

The terraces of the Mississippi system are probably the best known North American sequence (e.g. Fisk, 1951; Saucier, 1996; Blum \& Straffin, 2001). The sediment bodies recognized are huge, but they lack the fossiliferous interglacial intercalations seen in many European rivers, of considerable value for biostratigraphical dating. Instead the sequence has been dated with reference to soil formation, often in overlying loess deposits (Rodbell \& Forman, in press). Rivers on the eastern seaboard, however, have extensive Cenozoic sequences, some, such as in the case of the Susquehannah, extending back into the late Mesozoic (Pazzaglia \& Gardner, 1994). Recent work is also available on rivers in $\mathrm{N}$. California such as the Mattole (Merritts et al., 1994). The St Lawrence River has a well researched sequence extending back into the Middle Pleistocene (Ochietti \& Long, 1999), but Late Pleistocene glaciation has prevented earlier records surviving. In the more arid Yukon, in the extreme north, a lengthy late Cenozoic sequence has been preserved, however, one that furnishes evidence for the interaction between rivers and late pre-Quaternary glaciations (Froese et al., 2000).

\section{Middle East $\mathcal{E}$ North Africa}

From these relatively well researched areas, the project will expand into parts of the World where relatively little is known of long fluvial sequences. The Middle East is an area that has several important rivers, some of which are known to have terrace systems. For example, Tyràcek (1987) has recorded a full staircase of terraces, suggestive of climatically-driven formation at a Milankovitch scale, in the valley of the Euphrates River, Iraq. River terrace sequences in various parts of the Levant have attracted attention as a source of Palaeolithic artefacts (see below); examples are the terraces of the Orantes and the Kabir in Syria and deposits of the Jordan (Bar-Yosef, 1998; Table 1). Terrace sequences are known from the Nile and other North African rivers, although the arid hinterland means that the Nile is the only large river draining northwards to the Mediterranean (Said, 1993). The Nile terraces, from which the origins of the river can be traced back to the late Tertiary (Said, 1993), have yielded an important archaeological record (Sandford, 1934; Wendorf \& Schild, 1976; Paulissen \& Vermeersch, 1987). Rivers draining the Atlas Mountains of Morocco have built terraced alluvial sequences that trace drainage history back to the Miocene, albeit with large hiatuses (A. Ait Hssaine, pers. comm.). Blum \& Straffin (2001) have traced the history of wadis on the Saharan margins of Tunisia back into the Middle Pleistocene, the record being one of terraces and incised valley fills.

\section{India $\mathbb{E}$ Far East}

In India, as in the Middle East, fluvial deposits can be sources of Palaeolithic artifacts. For example, Middle Pleistocene alluvial deposits of the Pravara River, now between 2 and $15 \mathrm{~m}$ above the active floodplain, have yielded Acheulian (Lower Palaeolithic) artefacts (Kale \& Rajaguru, 1987; Mishra, 1991, 1994). The range of heights is suggestive of multiple terraces. Other important sources occur in Himalayan valleys in Nepal, of which the Babai system (Table 1) is just one example (Corvinus, 1998).

In China, the Yellow River has formed more than 20 terraces in response to uplift of the Tibetan Plateau by over $1 \mathrm{~km}(\mathrm{Li}, 1991)$. Other rivers have extensive terrace systems, amongst which the $\mathrm{Ba}$ and Chan are notable (Porter et al., 1992). An extensive terrace staircase, seemingly formed in synchrony with climatic fluctuation at the Milankovitch scale, is recorded from the Usui River in Japan (Sugai, 1993). In Korea, significant Quaternary terrace records are known from the Han, Nakdong, Keum, Youngan and Sumjn Rivers (Ju Yong Kim, personal communication).

\section{Australasia}

Typical Australian landscapes are not dominated by fluvial environments, but some rivers in the SE of the country have terrace sequences (Table 1). Rivers flowing into inland playa basins have also provided important records for environmental change. An example is the Cooper, which has left a sedimentary sequence representing the last two full climatic cycles, with important preservation of extinct megafauna (Nanson et al., 1999). The Charwell River in New Zealand has well documented terrace systems covering Pleistocene time-scales (Bull, 1991).

\section{South America}

In South America, significant sequences are known from the Parana and the Uruguay rivers of Argentina and the Magdalena/La Plata in Colombia (Table 1). Rifting has fashioned basins on the eastern side of the continent that have received fluvial sediments from the late Mesozoic onwards (Campbell et al., 1985; Andreis et al., 2000; Iriondo, 2000). 


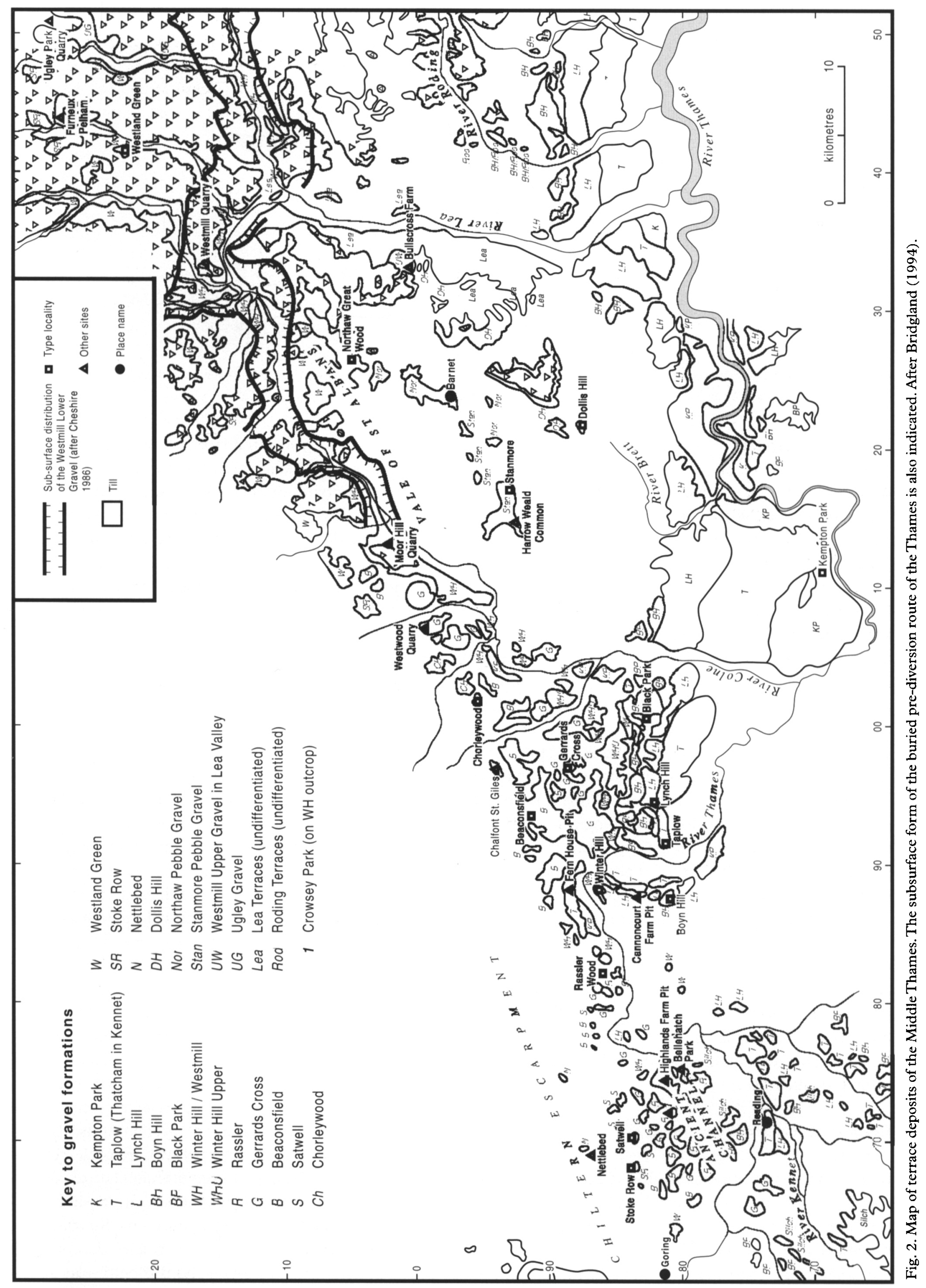




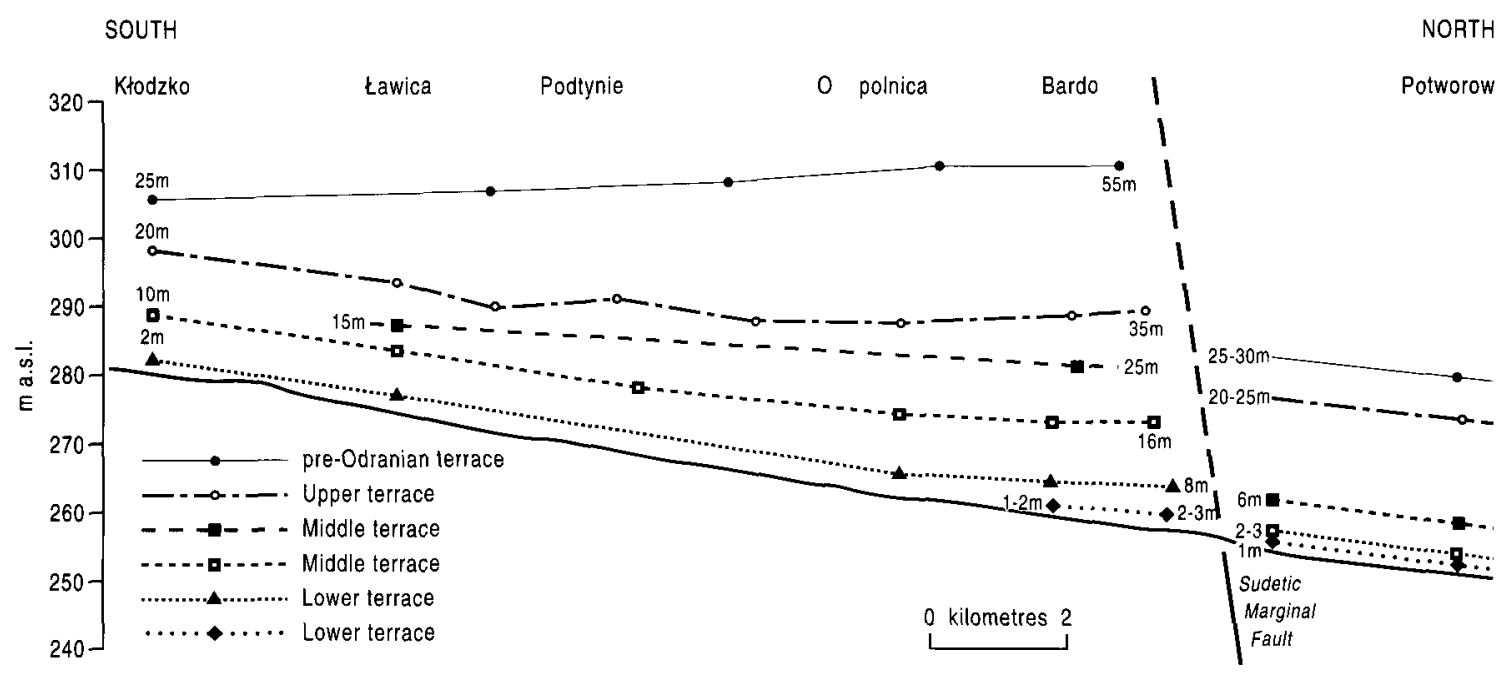

Fig. 3. Longitudinal profiles of terraces of the River Nysa Kłodzka, Sudeten Mountains and Sudetic Foreland, Poland. The effects of late Quaternary movement on the Sudetic Marginal fault are clear (after Krzyszkowski et al., 1998).

\section{Sub-Saharan Africa}

In southern Africa, some large rivers such as the Vaal Orange have significant terrace systems. The Vaal has an important archaeological record extending back considerably further in time than any of the better known NW European sequences (Butzer et al., 1973; Helgren, 1978, 1979; Hattingh \& Rust, 1999). The long-term stability of the African landcape has led to the preservation in this area of sequences that extend back into the early Neogene (Table 1). For example, the terraces of the Sundays River, eastern South Africa, have provided important evidence of postPalaeogene uplift history (Hattingh \& Rust, 1999).

Much less is known from tropical and equatorial Africa. In Rwanda, fluvial sequences have yielded important evidence for palaeohydrological evolution and the influence on drainage of volcanic eruptions (Schmidt \& Neuffer, 1995). The sequence in the Mukungwa valley, Rwanda, includes sediments yielding faunal and archaeological remains (Schmidt, 1996). Fluvial deposits are included amongst the sedimentary fill of the East African Rift Valley (Feibel et al., 1999; McBrearty, 1999), of great significance as the source of fossils charting early human history. Important archaeological records are also known from fluvio-lacustrine sequences in the rift valley in Congo (Harris et al., 1987).

\section{Proposed IGCP449 database}

Perhaps the most important aim of IGCP 449 is the compilation of an international database of information and evidence from fluvial sequences. The final specification of this database has yet to be decided, but it is already clear that certain types of data will be included. It is also intended that summary diagrams of various types will be archived.

Three main types of diagram are envisaged:

1. Maps showing distribution of outcrops and subsurface data where available (Fig. 2).

2. Longitudinal profile diagrams, which can reveal differences in gradient between different terrace levels, perhaps the result of differential crustal movements (Fig. 3).

3. Idealized transverse sections (in the case of terrace sequences these can be termed 'staircase diagrams'), which probably represent the greatest aid to understanding particular sequences (Fig. 1).

The accuracy of such diagrams, and any interpretations and age estimates that go into compiling them, is dependent upon the quality of the basic data. This can only be assessed through access to the data itself, so it is important that this is archived in some detail, which is the role of the main database. It is intended that the database will be disseminated via the Internet. It is likely that the content will include information such as follows below.

\section{Lithostratigraphy}

A sound stratigraphical framework is fundamental to the recording of data from fluvial archives. Formal lithostratigraphy (cf Hedberg, 1976) has been seldom undertaken in the case of river terraces except in a few countries, such as the Netherlands, the UK and North America, workers elsewhere preferring informal geomorphology-based nomenclature. An alternative would be to use allostratigraphic units (North American Commission on Stratigraphic Nomenclature NACSN, 1983), which were specifically designed to overcome the difficulties in apply- 
ing formal lithostratigraphical nomenclature to fluvial sequences. Effectively, however, it will be both necessary and desirable to make use of nomenclature already well established and this will be the normal policy.

Under this heading will be recorded basic information such as sediment types, height of sedimentary units above sea-level, downstream gradient and relation to adjacent non-fluviatile deposits. Thus the mapping of terrace geomorphology, an aspect of geological mapping, is subsumed here under the heading of lithostratigraphy, although others might wish to give it greater prominence.

\section{Biostratigraphy}

This is a traditional and well-tried method for establishing relative chronologies for fluviatile sequences. Applicable only where fossiliferous sediments have been preserved, the method has proved valuable in many parts of the World. The most useful fossil groups are those that can be identified readily to species level and those that have undergone significant evolutionary change within the late Cenozoic. Others may provide valuable palaeoenvironmental data that can be fed into climato-stratigraphical reconstructions. The most useful fossil groups are as follows:

\section{Vertebrates}

Recent work suggests that mammalian fossils offer a powerful tool for correlation of fluvial sequences with the global marine $\left(\delta^{18} \mathrm{O}\right)$ record of glacials and interglacials (Van Kolfschoten \& Turner, 1996; Preece \& Parfitt, 2000; Bridgland \& Schreve, 2001; Schreve, 2001). The bones and teeth of large mammals are commonly found in fluviatile deposits, rarely at sufficient frequency for any systematic samping strategy, although substantial collections from the days of manual quarrying survive in museums. Vertebrate remains from river deposits sometimes include hominid fossils, such as at Swanscombe, UK, in the Thames sequence (Conway et al., 1996), and Steinheim, Germany, within sediments of the River Murr (Adam et al., 1995). Mammals are especially valuable biostratigraphically, as they have undergone considerable evolution and numerous extinctions during the Neogene and Quaternary (Horáček, 1990). Small mammals and other small vertebrates are readily obtained from systematically collected samples by means of sieving (Rabeder, 1974, 1981; Fejfar \& Heinrich, 1983).

\section{Molluscs}

With freshwater, brackish and marine representatives, molluscs can record nearby land habitats as well as, in the lower reaches of rivers, the transition from the fluvial to the marine environment. Thus they allow sealevel changes to be detected at the downstream ends of river courses (e.g. Markova \& Mihailescu, 1994). The Mollusca supply important biostratigraphical and palaeoenvironmental information (Lozek, 1964a, 1964b; Horacek \& Lozek, 1988; Keen, 1990; Kovanda et al., 1995; Preece, 1995, 1999; Meijer \& Preece, 2000) and, in recent years, have provided the raw material for the powerful geochronological method based on the racemization of amino acids within mollusc shells (Miller et al., 1979; Bowen et al., 1989; Bates, 1994). Molluscs are also extremely important climato-stratigraphical tools, since they provide reliable evidence for palaeoclimate and palaeoenvironmental conditions.

An example of valuable biostratigraphical constraints provided by the study of molluscs is the occurrence of Corbicula fluminalis in British fluvial sequences, in which this bivalve occurs in deposits attributed to the OIS 11,9 and 7 interglacials, but is absent from those representing the last interglacial, OIS 5e (Keen, 1990; Bridgland, 1994; Preece, 1995, 1999). Recent reinvestigation of the record of this bivalve from the Netherlands suggests a similar pattern of occurrence there, with Corbicula absent from Eemian deposits, excepting reworked specimens (Meijer \& Preece, 2000).

\section{Palaeobotany}

This includes the study of pollen and spores, as well as macroscopic plant remains. Pollen, recognized as the most widespread source of environmental and stratigraphical evidence since the study of the Pleistocene interglacials began (Pike \& Godwin, 1953; West, 1956; Zagwijn, 1985), is often present in organic fluviatile sediments, such as those representing infilled channels (Maddy et al., 1998; Urban, 1995; Thomas, 2001). However, these generally record only a fragment of the time represented by any particular interglacial, although they may indicate in which part of the climatic (glacial-interglacial-glacial) cycle a sediment was laid down and contain key elements that may be of value for distinguishing between particular temperate-climate episodes (Tzedakis et al., 1997).

Macroscopic plant fossils provide valuable additional information, as they allow higher taxonomic resolution than is generally available from palynological data. Species that are poor pollen producers can also be represented. However, it is more difficult to undertake quantifiable studies and much less work has been carried out on macrofossils than on pollen. 


\section{Ostracods}

These provide important palaeoenvironmental information, particularly in relation to marine influences at the downstream ends of rivers (e.g. Dykan, 1999). However, they are of limited value for biostratigraphy (Griffiths, 2001; cf. Bridgland et al., 2001).

Beetles

Beetles have proved to be perhaps the most sensitive of the fossil groups for the reconstruction of palaeoclimate. The Mutual Climatic Range Method can provide limits of palaeotemperature based on coleopteran assemblages (Atkinson et al., 1987). This method is of obvious importance to climato-stratigraphy, but the biostratigaphical value of Coleoptera is equivocal, given the minimal evolution shown by the group during the late Cenozoic (cf. Coope, 2001).

\section{Geochronology}

Geochronological methods have already been applied widely to fluvial sequences in Europe, Asia and North America, and to the hominid-bearing deposits of the East African rift system, but less extensively elsewhere. The IGCP project will be a catalyst for this type of new research undertaking, which will be promoted where potential for dating has yet to be realized. It is anticipated that the following methods will be the principal sources of age estimates.

\section{Palaeomagnetism}

This method is valuable in providing isochrons. Location of the Matuyama-Bruhnes magnetic reversal is particularly important as a marker for the base of the Middle Pleistocene (780,000ka). This marker is an important element in the dating of the Somme (Antoine, 1994, Antoine et al., 2000) and Alpine (Fink et al., 1979) terrace sequences and has also been recognized in the Dniestr sequence (Markova \& Mihailescu, 1994). In some valleys (the Rhine and Danube are examples) it has been identified in both fluvial deposits and in aeolian overburden. Records in which magnetic reversals have been identified are indicated in Table 1 .

\section{Amino acid geochronology}

This has proved to be one of the most effective geochronological techniques for application to fluviatile sequences in north-west Europe, although its potential has yet to be realized elsewhere. The method is applicable in temperate latitudes over the last $0.5 \mathrm{Ma}$, although higher racemization rates in warmer climates will reduce this range. Recently the development of new preparation techniques has greatly en- hanced the reliability of this method (Stathopolos \& Hare, 1993; Sykes et al., 1995). The amino acid method has proved effective in the Thames, UK (Miller et al., 1979; Bowen et al., 1989, 1995), the Severn-Avon, UK (Maddy et al., 1991), the Somme, France (Bates, 1994), the Danube (Zöller et al., 1994; Oches \& McCoy, 1995) and the Dnieper, Ukraine (Oches et al., 2000). It can be applied to any fluviatile sequence in which molluscan fossils are commonly preserved, the shells providing the raw material for dating.

\section{Luminescence dating}

Luminscence methods, in particular IRSL (infrared stimulated luminescence) and GLSL (green light stimulated luminescence) applied to grains of quartz and feldspar, present perhaps the most exciting possibilities for the dating of fluvial sequences. Systematic dating of fluvial sequences using these methods has been shown to produce well constrained chronologies for sites unsuitable for dating by other techniques. These methods are applicable to sediments within the age range up to $200 \mathrm{ka}$; for example, using GLSL, Perkins and Rhodes (1994) dated coarse-grained, fluvially deposited sands at Tattershall, Lincolnshire, to beyond 100ka. Thermoluminesence (TL) and optically stimulated luminescence (OSL) methods have also been applied to loess overlying river terrace deposits. For example, OSL has been used to date Pleistocene sediments of fluvial and aeolian origin in the valley of the River Luni, India (Jain et al., 1999).

\section{Uranium Series Dating}

This method is well suited to dating travertines within fluvial sequences, such as those in East Germany and France, where the technique has been applied in the valleys of the River Ilm, at Weimar-Ehringsdorf (Blackwell \& Schwarcz, 1986), the River Wipper, at Bilzingsleben (Schwarcz et al., 1988), and the River Allier (Veldkamp \& Kroonenberg, 1993). Travertines within River Danube sequences in Hungary have also been dated using this method (Hennig et al., 1983).

\section{Potassium-Argon $\left({ }^{40} \mathrm{~K} /{ }^{40} \mathrm{Ar}\right.$ and $\left.{ }^{40} \mathrm{Ar} /{ }^{39} \mathrm{Ar}\right)$ Dating}

The K-Ar dating technique has been widely applied for the dating of igneous rocks with recent developments, particularly in ${ }^{40} \mathrm{Ar} /{ }^{39} \mathrm{Ar}$ dating, allowing the possible dating of Quaternary materials with relatively high temporal resolution (Richards \& Smart, 1991). In many areas fluvial sediments are intercalated with tephras and lava flows etc. (Table 1), allowing the possibility of utilizing these techniques to constrain the ages of fluvial sequences. This method has been used the date the Rhine terraces with reference 
to ash layers from volcanism in the Eifel region (Boogard et al., 1989), providing geochronological control within important sequences such as that at Kärlich (Van Kolfschoten \& Turner, 1996). It has also been claimed as a measure of uplift, when used to date Pleistocene basalt flows that have invaded and diverted the Kula River in western Turkey, lavas of progressively younger ages occupying successively lower altitudes as a result of incision by the river (Bunbury et al., 2001).

\section{Cosmogenic Isotopes}

This method is based upon the modelling of cosmogenic isotope $\left({ }^{26} \mathrm{Al},{ }^{36} \mathrm{Cl}\right.$ and $\left.{ }^{10} \mathrm{Be}\right)$ uptake on newly exposed rock/boulder surfaces. Although to date there have been relatively few fluvial studies using this technique (e.g. the Indus: Burbank et al., 1996), it has considerable potential, especially for use in sequences that include strath (erosional) terraces and where there are gorges cut into bedrock.

\section{Archaeology}

In north-west Europe, where some of the best-known studies of river terrace sequences have been carried out, many fluviatile deposits are an important repository for Palaeolithic artefacts, from which a record of early human occupation can be reconstructed (much more readily than from rare occurrences of hominid fossils). Indeed, in Europe, river terrace deposits have provided the bulk of the artifactual evidence for the presence of Lower Palaeolithic hunter-gatherers (e.g. Wymer, 1968, 1988, 1999; Mania, 1995; Tuffreau \& Antoine, 1996; Roebroeks \& Van Kolfschoten, 1995).

Fluvial sequences in the Near East, Middle East and parts of Asia and Africa are also important sources of artefacts. The records of Lower Palaeolithic artefacts from the sediments of the Pravara River in India and the Mukungwa River in Rwanda have already been cited. Artefact discoveries from fluvial sequences in southern Africa record the activities of early humans in that area during and since the Early Pleistocene, perhaps even the late Tertiary (Butzer et al., 1973; Helgren, 1978, 1979; Beaumont \& Morris, 1990). As already mentioned, some of the evidence for the earliest known phases of human history also comes from fluvial sequences, within the infill of the Turkana and Baringo Basins of the East African rift systems (Feibel et al., 1999). The progression of humans northwards from Africa into Eurasia is likely to be charted in fluvial sequences across these areas, with the earliest appearances in the regions closest to the African origins.

\section{Event stratigraphy}

In many parts of the world, particularly the mid-latitudes of the Northern Hemisphere, detailed stratigraphical sequences are recognized on the basis of the interpretation of glaciogenic and lacustrine sedimentary archives that have been independently dated and correlated. Whereas the lacustrine sequences generally reflect short-lived basins (most became infilled within a single climatic cycle) that are stratigraphically isolated from other Quaternary sediments, glacial deposits often interdigitate with fluvial sequences and can provide important markers, particularly where glaciation had a significant effect on the river system concerned. Glacial diversions of rivers in northern Europe provide useful examples (e.g. Gibbard, 1988), visible in fluvial sequences as a result of changes in sediment provenance and composition. Rivers can also be diverted by the process of river capture (Bishop, 1995; Pastre \& Leroyer, 1997; Pissart et al., 1997), with changes in catchment again providing markers within fluvial sequences.

Marine transgressions provide further significant markers, usually at the opposite (i.e. lower) ends of fluvial systems to glacial markers. The highest marine transgressions will generally record the warmest interglacials, although the severity of preceding glaciation can be a significant factor, through delayed isostatic recovery (Kukla \& Cílek, 1996). The overprinting of high-sea-level events onto background uplift is the basis for the best sequences, in which fluvial sediments may interdigitate with estuarine sequences or even raised beaches. A good example of the latter is seen in the Sussex coastal plain, UK (Bates, 2001). The record from the northern margins of the Black Sea is an excellent example of the important palaeoclimatic archives that can be derived from river systems repeatedly affected by marine transgressions (Markova \& Mihailescu, 1994; Matoshko et al., this volume).

Volcanic eruptions, already seen as a provider of datable layers interbedded within fluvial sequences, can also provide important markers. In extreme cases they might be a further cause of diversions (Kroonenburg et al., 1981; Pastre et al., 1997); less drastically, they can introduce new material into a catchment that can be recognized in sediments that post-date the eruption, a good example being the augite from eruption in the Eifel at c. $480 \mathrm{ka}$ (Van Kolfschoten \& Turner, 1996).

\section{Discussion}

A key aim of the IGCP project is to cross-correlate fluvial sequences by correlating the record from each 
river system with the oceanic oxygen isotope record, which will be achieved with reference to all available data. This will principally constitute applying biostratigraphical and geochronological evidence, using the established lithostratigraphy as a framework (see above). Thus by building on regional models, established early on, it should be possible to progress towards the main objective of this project: the global correlation of fluvial sequences. The resultant data will be valuable for comparison of landscape evolution between different areas.

The correlation programme will also provide better understanding and dating control for those fluvial sequences that are the context for archives of mammalian evolution and human occupation during the late Cenozoic. A significant proportion of the data on both of the above comes from fluvial sequences. Even where key sites occur in other environmental contexts, a better dated regional fluvial sequence could provide an improved framework for correlation. Thus cave and lacustrine sequences, generally isolated within the landscape and within the geological record, might be correlated with the regional fluvial sequence by means of biostratigraphy. The established regional fluvial sequence would provide a framework into which the 'floating' lacustrine or cave sediments could be fitted. Conversely the cave sediments might provide an independent geochronology based on the uranium series dating of speleothems (Smart, 1991), providing an important cross-check for the dating of the fluvial sequence. Lacustrine sequences can provide a more complete record of interglacial cycles than is likely to be found in fluvial sediments, so again, if these can be linked into the regional stratigraphical framework of fluvial sediments, the palaeoclimatic record as a whole will be much enhanced (cf Thomas, 2001).

It is hoped that many will want to contribute information to the IGCP 449 database, in which case they should contact one of the authors or visit the project's internet site

(http://www.qra.org.uk/FLAG/IGCP449.htm). It is anticipated that subgroups will develop to promote particular strands of the project, some regionally based, but including thematic groups working on mammals, molluscs and archaeology from fluvial sequences.

\section{Acknowledgements}

The authors wish to thank Dariusz Krzyszkowski for his comments on an earlier draft of this paper. Manfred Frechen and Sampat Tandon, acting as referees, provided useful comments and additional references. Rob Westaway kindly assisted with literature sources and information added to Table 1 , as well as providing comments at the revision stage. Cartographers Steven Allen, David Hume and Chris Orton (Department of Geography, University of Durham) produced the final diagrams. D.R. Bridgland acknowledges funding by the Leverhulme Trust (1997-2000) for a project entitled 'Mammalian biostratigraphy of NW European rivers'. This paper is a contribution to IGCP 449 (Global Correlation of Late Cenozoic fluvial deposits).

\section{References}

Acharyya, S.K. \& Basu, P.K., 1993. Toba ash on the Indian subcontinent and its implication for correlation of Late Pleistocene alluvium. Quaternary Research 40: 10-19.

Adam, K.D., Bloos, G. \& Ziegler, R., 1995. Stop 11: Steinheim / Murr, N of Stuttgart - Locality of Homo steinheimensis. In: Schirmer, W. (ed.): Quaternary field trips in Central Europe (vol. 2). Verlag Dr. Friedrich Pfeil (Munich): 727-728.

Alekseev, M.N., 1996. Possible 'Cromerian Comple' equivalent sequences in the Russian Plain. In: Turner, C. (ed.): The early Middle Pleistocene in Europe. Balkema (Rotterdam): 273-277.

Alekseev, M.N. \& Drouchits, V.A., 1997. Correlation of Pleistocene events of west and east Russian Arctic shelf regions. IGCP 396 (Durham) Abstract booklet: 1-2.

Allen, L.G. \& Gibbard, P.L., 1994. Pleistocene evolution of the Solent River of southern England. Quaternary Science Reviews 12: 503-528.

Allen, L.G., Gibbard, P.L., Petit, M.E., Preece, R.C. \& Robinson, J.E., 1996. Late Pleistocene interglacial deposits at Pennington Marshes, Lymington, Hampshire, Southern England. Proceedings of the Geologists'Association 107: 39-50.

Andreis, R.R., Ramos, R.R.C., Mello, C.L. \& Ribeiro, A., 2000. Tertiary fluvial systems of the Resende basin, southern Rio de Janeiro State, Brazil. Field Trip guide, 31 st International Geological Congress: $27 \mathrm{pp}$.

Antoine, P., 1990. Chronostratigraphie et environnement du palaeolithique du bassin de la Somme. Publications du Centre Européen de Recherches Préhistoriques no. 2, Université de Sciences et Techniques de Lille, Flandres/Artois.

Antoine, P., 1994. The Somme valley terrace system (northern France): a model of river response to Quaternary climatic variations since 800,000 bp. Terra Nova 6: 453-464.

Antoine, P., Lautridou, J.P. \& Laurent, M., 2000. Long-term fluvial archives in NW France: response of the Seine and Somme rivers to tectonic movements, climate variations and sea-level changes. Geomorphology 33: 183-207.

Atkinson, T.C., Briffa, K.R. \& Coope, G.R., 1987. Seasonal temperatures in Britain during the past 22000 year, reconstructed using beetle remains. Nature 325: 587-592.

Bar-Yosef, O., 1998. Early colonizations and cultural continuities in the Lower Palaeolithic of western Asia. In: Petraglia, M.D. \& Korisettar, R. (eds): Early Human Behaviour in Global Context. Routledge (London): 221-279.

Bates, M.R., 1994. Quaternary aminostratigraphy in northwestern France. Quaternary Science Reviews 12: 793-809.

Bates, M.R., 2001 The meeting of the waters: raised beaches and river gravels of the Sussex Coastal Plain/Hampshire Basin. In: Wenban-Smith, F.F. \& Hosfield, R.T. (Eds): Palaeolithic archaeology of the Solent River. Lithic Studies Society Occasional Paper 7. Iithic Studies Society (London): 27-45. 
Beaumont, P. \& Morris, D., 1990. Guide to the archaeological sites in the Northern Cape. McGregor Museum, Kimberley, South Africa.

Benito, G., Gutiérrez, F., Pérez-González, A. \& Macado, M.J., 2000. Geomorphological and sedimentological features in Quaternary fluvial systems affected by solution-induced subsidence (Ebro basin, NE-Spain). Geomorphology 33: 209-224.

Benda, L. (ed.) 1995. Das Quartär Deutschlands. Gebrüder Borntraeger (Berlin): $408 \mathrm{pp}$.

Bergeing, J.P. \& Gilliard, P., 1997. Geomorphologie des terrasses $\mathrm{du}$ fleuve Niger à la latitude du Parc National du W, Niger. Zeitschrift für Geomorphologie N.F. 41: 491-504.

Bibus, E., 1980. Zur Relief-, Boden- und Sedimententwicklung am unteren Mittelrhein. Frankfurter geowissenschaftliche Arbeiten, Serie D 1:296 pp.

Bibus, E. \& Wesler, J., 1995. The middle Neckar as an example of fluviomorphological processes during the Late Quaternary Period. Zeitschrift für Geomorphologie N.F. Supplement Band 100: 15-26.

Bishop, P., 1995. Drainage rearrangement by river capture, beheading and diversion. Progress in Physical Geography 19: 449473.

Bishop, P. \& Brown, R., 1992. Denudational isostatic rebound of intraplate highlands: the Lachlan River valley, Australia. Earth Surface Processes and Landforms 17: 345-360.

Bishop, P., Young, R.W. \& McDougall, I., 1985. Stream profile change and longterm landscape evolution: early Miocene and modern rivers of the East Australian highland crest, central New South Wales, Australia. Journal of Geology 93: 455-471.

Blackwell, B. \& Schwarcz, H.P., 1986. U-Series analyses of the Lower Travertine at Ehringsdorf, DDR. Quaternary Research 25: 215-222

Blüberger, G., 1996. Wie die Donau nach Wien kam. Von den Quellen bis zur Hainburger Pforte. Böhlau Verlag (Vienna): 285 pp.

Blum, M.D. \& Straffin, E.C., 2001. Fluvial responses to external forcing: Examples from the French Massif Central, the Texas Coastal Plain (USA), the Sahara of Tunisia, and the Lower Mississippi Valley (USA). In: Maddy, D., Macklin, M.G. \& Woodward, J. (Eds): River Basin Sediments Systems: Archives of Environmental Change. Balkema (Rotterdam): 195-228.

Bowen, D.Q., Hughes, S., Sykes, G.A. \& Miller, G.H., 1989. Landsea correlations in the Pleistocene based on isoleucine epimerization in non-marine molluscs. Nature 340: 49-51.

Bowen, D.Q., Sykes, G.A., Maddy, D., Bridgland, D.R. \& Lewis, S.G., 1995. Aminostratigraphy and amino acid geochronology of English lowland valleys: the Lower Thames in context. In: Bridgland, D.R., Allen, P. \& Haggert, B.A. (Eds): The Quaternary of the lower reaches of the Thames, Quaternary Research Association Field Guide (Durham): 61-63.

Bridgland, D.R., 1994. Quaternary of the Thames. Chapman \& Hall (London): $441 \mathrm{pp}$

Bridgland, D.R., 2000. River terrace systems in north-west Europe: an archive of environmental change, uplift and early human occupation. Quaternary Science Reviews 19: 1293-1303.

Bridgland, D.R. \& D'Olier, B., 1995. The Pleistocene evolution of the Thames and Rhine drainage systems in the southern North Sea Basin. In: Preece, R.C. (ed.): Island Britain: a Quaternary Perspective. Geological Society of London Special Publication No. 96: 27-45.

Bridgland, D.R., Preece, R.C., Roe, H.M., Tipping, R.M., Coope, G.R., Field, M.H., Robinson, J.E., Schreve, D.C. \& Crowe, K., 2001. Middle Pleistocene interglacial deposits at Barling, Essex, UK: evidence for a longer chronology for the Thames terrace sequence. Journal of Quaternary Science 16: 813-840.
Bridgland, D.R. \& Schreve, D.C., 2001. River terrace formation in synchrony with long-term climatic fluctuation: examples from southern Britain. In: Maddy, D., Macklin, M. \& Woodward, J. (Eds): River Basin Sediments Systems: Archives of Environmental Change. Balkema (Rotterdam): 229-248.

Brunnacker, K., Löscher, M., Tillmans, W. \& Urban, B., 1982. Correlation of the Quaternary terrace sequence in the lower Rhine valley and northern Alpine foothills of central Europe. Quaternary Research 18: 152-173.

Bull, W.B., 1991. Geomorphic Responses to Climatic Change. Oxford University Press: $326 \mathrm{pp}$.

Bull, W. B. \& Kneupfler, P.L.K., 1987. Adjustments by the Charwell River, New Zealand, to uplift and climatic changes. Geomorphology 1: 15-32.

Bunbury, J.M., Hall, L., Anderson, G.J. \& Stannard, A., 2001. The determination of fault movement history from the interaction of drainage with volcanic episodes. Geological Magazine 138: 185192.

Burbank, D.W., Leland, J., Fielding, E., Anderson, R.S., Brozovic, N., Reid, M.R. \& Duncan, C., 1996. Bedrock incision, rock uplift and threshold hillslopes in the northwestern Himalayas. Nature 379: 505-510.

Butzer, K.W., Helgren, D.M., Fock, G.J. \& Stuckenrath, R., 1973. Alluvial terraces of the lower Vaal River, South Africa: a reappraisal and reinterpretation. Journal of Geology 81: 341-362.

Campbell, K., Frailey, C. \& Arellano, J., 1985. The geology of the Rio Beni: further evidence for Holocene flooding in Amazonia. Science 364: 1-18.

Conway, B., McNabb, J. \& Ashton, N., 1996. Excavations at Barnfield Pit, Swanscombe, 1968-72. British Museum, London, occasional paper $94: 266 \mathrm{pp}$.

Coope, G.R. 2001. Biostratigraphical distinction of interglacial coleopteran assemblages from southern Britain attributed to Oxygen Isotope Stages 5e and 7. Quaternary Science Reviews 20: 1717-1722.

Corvinus, G., 1998. Lower Palaeolithic occupations in Nepal in relation to South Asia. In: Petraglia, M.D. \& Korisettar, R. (eds): Early Human Behaviour in Global Context. Routledge (London): 391-417.

De Mauro, C.A. \& Christofoletti, A., 1984. Aspectos fisico-geograficos da Regiao Administrativa de Aracatuba. Geociencias (Sao Paulo) 3: 139-167.

Díaz del Olmo, F., Vallespí, E., Baena, R. \& Recio, J.M., 1989. Terrazas pleistocenas del Guadalquivir occidental: geomorfologia, suelos, paleosuelos y secuencia cultural. In: El Cuaternário en Andalucia occidentale, AEQUA, Sevilla, Monografias 1: 33-42.

Díaz del Olmo, F. Vallespí, E. \& Baena Escudero, R., 1993. Cuaternário y secuencia paleolítica en las terrazas del bajo y medioGuadalquivir: aluvionamientos, coluviones, suelos y paleosuelos. VI Jornadas de Arqueología Andaluza. Junta de Andalucia, Huelva.

Dodonov, A.E., Deviatkin, E.V., Ranov, V.A., Khatib, K. \& Nseir, H., 1993. The Latamne Formation in the Orontes river valley. In: Sanlaville, P., Besançon, J., Copeland, L. \& Muhesen, S. (eds): Le Paléolithique de la vallée moyenne de l'Oronte (Syrie): Peuplement et environnement. British Archaeological Review, International Series, 587: 189-194.

Domas, J., 1994. The Late Cenozoic of the Al Ghab Rift, NW Syria. Antropoziokum 21: 57-73.

Dykan, N., 1999. Extent of Pleistocene freshwater and estuarine Ostracoda in the territory of Ukraine. Geological Journal (Ukraine) 3: 55-59.

Feibel, C.S, Kingston, J.D. \& Ashley, G.M., 1999. Environmental change and early human evolution in East Africa: aspects of geological context and sampling. Book of Abstracts, XV INQUA 
Congress, Durban, South Africa: 60-61

Fejfar, O. \& Heinrich, W.D., 1983. Arvolicoden-Sukzession und Biostratigraphie des Oberpliozäns und Quatärs in Europe. Schriften Reihe geologische Wissenschaften 19/20: 61-109.

Fink, J., Koci, A., Kohl, H. \& Pevzner, M.A., 1979. Palaeomagnetic research in the northern foothills of the Alps and the question of correlation of terraces in the upper reach of the Danube. IGCP Project 73/1/24 - Quaternary Glaciations in the Northern Hemisphere, Rep. No. 5: 108-116.

Fisk, H.N., 1951. Loess and Quaternary geology of the Lower Mississippi Valley. Journal of Geology 59: 333-356.

Froese, D.G.. Barendregt, R.W., Enkin, R.J. \& Baker, J., 2000. Paleomagnetism of late Cenozoic terraces of the lower Klondike valley, Yukon: Evidence for multiple late Pliocene-early Pleistocene glaciations. Canadian Journal of Earth Sciences 37: 863877 .

Gabunia, L. \& Vekua, A., 1995. A Plio-Pleistocene hominid from Dmansi, east Georgia, Caucasus. Nature 373: 509-512.

Gibbard, P.L., 1985. The Pleistocene history of the Middle Thames Valley. Cambridge University Press: $155 \mathrm{pp}$.

Gibbard, P.L., 1988. The history of the great northwest European rivers during the past three million years. Philosophical Transactions of the Royal Society of London B318: 559-602.

Gibbard, P.L., 1994. Pleistocene History of the Lower Thames Valley. Cambridge University Press: 229 pp.

Giles Pancheco, F., Santiago, A., Gutiérrez, J.M., Mata, E. \& Aguilera, L., 1989. El poblamiento paleolítico en el valle del rio Gadalete. In: El Cuaternário en Andalucia occidentale, AEQUA, Sevilla: 43-57.

Griffiths, H.I., 2001. Ostracod evolution and extinction - its biostratigraphic value in the European Quaternary. Quaternary Science Reviews 20: 1743-1751.

Halouzka, R. \& Minarikova, D., 1977. Stratigraphic correlation of Pleistocene deposits of the River Danube in the Vienna and Komarno Basins. Antropozoikum 1 1: 7-55.

Harris, J.W.K., Williamson, P.G., Verniers, J., Tappen, M.J., Stewart, K., Helgren, D., de Heinzelin, J., Boaz, N. \& Bellomo, R, 1987. Late Pliocene hominid occupation in Central Africa: the setting, context and character of the Senga 5A Site, Zaire. Journal of Human Evolution 16: 701-728.

Hattingh, J. \& Rust, I.C., 1999. Drainage evolution and morphological development of the Late Cenozoic Sundays River, South Africa. In: Miller, A.J. \& Gupta, A. (Eds): Varieties of Fluvial Form, Wiley (Chichester): 145-166.

Hedburg, H.D., 1976. International stratigraphic guide. Wiley \& Sons (New York): $200 \mathrm{pp}$

Helgren, D.M., 1978. Acheulian settlement along the lower Vaal River, South Africa. Journal of Archaeological Science 5: 39-60.

Helgren, D.M., 1979. River of diamonds: an alluvial history of the lower Vaal basin. University of Chicago, Department of Geography Research Paper 185.

Hennig, G.J., Grün, R., Brunnacker, K. \& Pecsi, M., 1983. Th230/U-234 sowie ESR-Altersbestimmungen einiger Travertine in Unharn. Eiszeitalter und Gegenwart 33: 9-19.

Horáček, I., 1990. On the context of Quaternary Arvicolid evolution: changes in community development. International Symposium on the Evolution, Phylogeny and Biostratigraphy of the Arvicolids: 201-222.

Horáček, I. \& Lozek, V., 1988. Paleozoology and the Mid-European Quaternary past: scope of approach and selected results. Rozpravy Ėeskoslovenské Akademie Vid 98: 1-102.

Howell, F.C., Haesaerts, P. \& de Heinzelin, J., 1988. Depositional environments, archaeological occurrences and hominids from Members $\mathrm{E}$ and $\mathrm{F}$ of the Shungura Formation (Omo Basin, Ethiopia). Journal of Human Evolution 16: 665-700.
Iriondo, M., 1980. El Cuaternario de Entre Rios. Revista de la Asociacion de Ciencias Naturales del Litoral 11:125-141.

Iriondo, M.H., 2000. The Neogene of the Llanos-Chaco-pampa Depression. Episodes 22: 226-231.

Jain, M., Tandon S.K., Bhatt, S.C., Singhvi, A.K. \& Mishra, S., 1999. Alluvial and aeolian sequences along the River Luni, Barmer District: physical stratigraphy and feasibility of luminescence chronology methods. Memoir Geological Society of India, No 42: 273-295.

Jain, M., Woodcock, N.H. \& Tandon S.K., 1998. Neotectonics of western India: evidence from deformed Quaternary fluvial sequences, Mahi River, Gujarat. Journal of the Geological Society, London 155: 897-901.

Kale, V.S. \& Rajaguru, S.N., 1987. Late Quaternary alluvial history of the north-western Deccan upland region. Nature 325: 612614.

Keen, D.H., 1990. Significance of the record provided by Pleistocene fluvial deposits and their included molluscan faunas for palaeoenvironmental reconstruction and stratigraphy: case study from the English Midlands. Palaeogeography, Palaeoclimatology, Palaeoecology 80: 25-34.

Klostermann, J., 1992. Das Quartär der Niederrheinischen Bucht. Geologisches Landes-Amt, Krefeld: 200 pp.

Korisettar, R. \& Rajaguru, S.N., 1998. Quaternary stratigraphy, palacoclimate and the Lower Palaeolithic of India. In: Petraglia, M.D. \& Korisettar, R. (Eds): Early Human Behaviour in Global Context. Routledge (London): 304-342.

Kovanda, J., Smolikova, L. \& Horacek, I., 1995. New data on four classic loess sections in Lower Austria. Antropoziokum 22: 6385.

Kroonenburg, S., Pessoa, M.R., Silvestre L.A.L. \& Pastana, J.M.D.N., 1981. Ignimbritas Pliopleistocenicas en el suroeste del Huila, Colombia y su influencia en el desarrollo morfologico. Revista CIAF 6, no.1-3: 293-314.

Krzyszkowski, D. \& Biernat J., 1998. Terraces of the Bystrzyca river valley, Middle Sudates, and their deformation along the Sudetic Marginal Fault. Geologia Sudetica 31: 241-258.

Krzyszkowski, D., Przybylski, B. \& Badura, J., 1998. Late Cainozoic evolution of the Nysa K3odzka river system between K3odzko and Kamieniec Z1bkowicki, Sudates Mts, southwestern Poland. Geologia Sudetica 31: 133-155.

Krzyszkowski, D., Przybylski, B. \& Badura, J., 2000. The role of neotectonics and glaciations along the Nysa-Klodzka River in the Sudeten Mountains (southwestern Poland). Geomorphology 33: 149-166.

Kukla, G.J., 1975. Loess stratigraphy of Central Europe. In: Butzer, K.W. \& Isaac, G.L. (Eds): After the Australopithecines: Stratigraphy, Ecology and Culture Change in the Middle Pleistocene. Mouton (The Hague): 99-188.

Kukla, G.J., 1977. Pleistocene land-sea correlations. I. Europe. Earth Science Reviews 13: 307-374.

Kukla, G. \& Cilek, V., 1996. Plio-Pleistocene megacycles: record of climate and tectonics. Palaeogeography, Palaeoclimatology, Palaeoecology 120: 171-194.

Lautridou, J.P., Monnier, J.L., Morzadec-Kerfourn, M.T., Somml, J. \& Tuffreau, A., 1983. Les subdivisions du Pleistocène de la France septentrionale: stratigraphie et paleolithique. In: Billards, A., Conchon, O. \& Shotton, F.W. (Eds): Quaternary glaciations in the Northern Hemisphere. IGCP Project 73-1-24. Report No. 9, Unesco International Geological Correlation Programme, Paris: $148-170$.

Lautridou, J.-P., Auffret, J.-P., Baltzer, A., Clet, M., Lécolle, F., Lefebvre, D., Lericolais, G., Roblin-Jouve, A., Balescu, S., Carpentier, G., Descombes, J.-C., Occhietti, S. \& Rousseau, D.-D., 1999. The river Seine, the river Manche. Bulletin de la Société 
Géologique de France 170: 545- 558 (in French with English summary).

Leng, J., 1998. Early Palaeolithic quartz industries in China. In: Petraglia, M.D. \& Korisettar, R. (Eds): Early Human Behaviour in Global Context. Routledge (London): 418-436.

Lericolais G., Auffret J.P. \& Bourillet J.F., 1997. Evolution plioquaternaire du fleuve Manche: Stratigraphie et Géomorphologie de la confluence de la Paléo-Somme et de la Paléo-Seine. Academie de Sciences de France, Montpellier: 23 pp.

Li, J., 1991. The environmental effects of the uplift of the QinghaiXizang Plateau. Quaternary Science Reviews 10: 479-483.

Lozek, V., 1964a. Quartärmollusken der Tschechoslowakei. Rozpravi Ústredního ústavu geologického 31: 1-347.

Lozek, V., 1964b. Neue Mollusken aus dem Altpleistozän Mittleeuropas. Archiv für Molluskenkunde 93: 193-199.

McBrearty, S., 1999. The archaeology of the Kapthurin Formation. In Andrews, P. \& Banham, P. (Eds): Late Cenozoic Environments and Hominid Evolution: a tribute to Bill Bishop. Geological Society, London: 143-156.

Maddy, D., 1997. Uplift-driven valley incision and river terrace formation in southern England. Journal of Quaternary Science 12: 539-545.

Maddy, D. \& Bridgland, D.R., 2000. Accelerated uplift resulting from Anglian glacioisostatic rebound in the Middle Thames valley, UK: evidence from the terrace record. Quaternary Science Reviews 19: 1589-1604.

Maddy, D., Bridgland, D.R. \& Green, C.P., 2000. Crustal instability and the development of certain English rivers. Geomorphology 33: 167-181.

Maddy, D., Green, C.P., Lewis, S.G. \& Bowen, D.Q., 1995. Pleistocene Geology of the Lower Severn Valley. Quaternary Science Reviews 14: 209-222.

Maddy, D., Keen, D.H., Bridgland, D.R. \& Green, C.P., 1991. A revised model for the Pleistocene development of the River Avon, Warwickshire. Journal of the Geological Society of London 148: 473-484.

Maddy D., Lewis, S.G., Scaife, R.G., Bowen, D.Q., Coope, G.R., Green, C.P., Keen, D.H., Rees-Jones, J., Hardaker, T., Parfitt, S. $\&$ Scott, K., 1998. The upper Pleistocene deposits at Cassington, near Oxford, UK. Journal of Quaternary Science 13: 205-231.

Mania, D., 1995. The earliest occupation of Europe: the Elbe-Saale region (Germany). In: Roebroeks, W. \& Van Kolfschoten, T. (Eds): The Earliest Occupation of Europe. University of Leiden, The Netherlands: 85-101.

Markova, A.K. \& Mihailescu, C.D., 1994. Correlation of Pleistocene marine and continental deposits from the Northwestern Black Sea Region. Stratigraphy and Geological Correlation. Vol. 2, Nr.4. Moscow: 87-95.

Mather, A.E., Sliva, P.G., Goy, J.L., Harvey, A.M. \& Zazo, C., 1995. Tectonics versus climate: an example from late Quaternary aggradational and dissectinal sequences of the Mula basin, southeast Spain. In: Lewin, J., Macklin, M.G. \& Woodward, J.C. (eds): Mediterranean Quaternary river environments. Balkema (Rotterdam): 77-87.

A.V. Matoshko, P.F. Gozhik \& Ivchenko, A.S., 2002. This volume. The fluvial archive of the Middle and Lower Dnieper (a review).

Meijer, T. \& Preece, R.C., 2000. A review of the occurrence of Corbicula in the Pleistocene of North-West Europe. Geologie en Mijnbouw/Netherlands Journal of Geosciences 79: 241-255.

Merritts, D.J., Vincent, K.R. \& Wohl, E.E., 1994. Long river profiles, tectonism, and eustasy: a guide to interpreting fluvial terraces. Journal of Geophysical Research 99: 14,031-14,050.

Miller, G.H., Hollin, J.T. \& Andrews, J., 1979. Aminostratigraphy of UK Pleistocene deposits. Nature 281: 539-543.

Mishra, S., 1991. Prehistoric and Quaternary studies at Nevasa: the last forty years. Memoirs of the Geological Society of India, No 32: 324-332.

Mishra, S., 1992. The age of the Acheulian in India: new evidence. Current Anthropology 33, 325-328.

Mishra, S., 1994. The South Asian Lower Palaeolithic. Man and Environment 19: 57-72.

Nanson, G.C., East T.J. \& Roberts R.G., 1993. Quaternary stratigraphy, geochronology and evolution of the Magela Creek catchment in the monsoon tropics of northern Australia. Sedimentary Geology 83: 277-302.

Nanson, G.C., Coleman, M. \& Price, D.M., 1999. Alluvial and aeolian evidence for major drainage disruption and changes in wind direction during the last full glacial cycle in central Australia. Book of Abstracts, XV INQUA Congress, Durban, South Africa: 130-131.

NACSN [North American Commission on Stratigraphic Nomenclature] 1983. North American Stratigraphic Code. American Association of Petroleum Geologists, Bulletin 67: 841-875.

Niculescu, G.H., 1963. Terasele Teleajenului in zona subcarpatia cu privire speciala cesupra miscarilar neotectonice cua ternare. Proberma de geografia 9:57-83.

Oches, E.A. \& McCoy, W.D., 1995. Aminostratigraphic evaluation of conflicting age estimates for the 'Young Loess' of Hungary.Quaternary Research 44: 160-170.

Oches, E.A., McCoy, W.D. \& Gnieser, D., 2000. Aminostratigraphic correlation of loess-paleosol sequences across Europe. In: Goodfriend, G.A., Collins, M.J., Fogel, M.L., Macko, S.A. \& Wehmiller, J.F. (eds): Perspectives in amino acid and protein geochemistry. Oxford University Press (New York): 331-348.

Ochietti, S. \& Long, B., 1999. Middle to Upper Quaternary facies successions and depositional systems in the St Lawrence Basin. Programme \& Abstracts, IGCP 396 4th Annual Conference, Cape Town, South Africa: 28.

Ozaner, F., 1992. Detecting the polycyclic drainage evolution in Kula region (western Turkey) using aerial photographs. ITC Journal 1992-3: 249-253.

Pastre, J-F., Defive, E., Gablier, F. \& Lageat, Y., 1997. Changements hydrographiques et volcanisme plio-quaternaire dans les bassins de la Loire et de l'Allier (Massif central, France). Géographie physique et quaternaire 51:295-314.

Pastre, J-F. \& Leroyer, C., 1997. La capture du Grand-Morin par la Marne, (Bassin parisien, France): âge et mécanisme. Géographie physique et quaternaire 51:347-350.

Paulissen, E. \& Vermeersch, P.M., 1987. Earth, Man and climate in the Egyptian Nile valley during the Pleistocene. In: Close, A.E. (ed.): Prehistory of Arid North Africa, Southern Methodist University Press: 29-67.

Pazzaglia, F.J. \& Gardner, T., 1994. Late Cenozoic flexural deformation of the middle U.S. Atlantic passive margin. Journal of Geophysical Research 99: 12,143-12,157.

Perkins, N.K. \& Rhodes, E.J., 1994. Optical dating of fluvial sediments from Tattershall, U.K. Quaternary Science Reviews 13: 517-520.

Petraglia, M.D., 1998. The Lower Palaeolithic of India and its bearing on the Asian record. In: Petraglia, M.D. \& Korisettar, R. (Eds): Early Human Behaviour in Global Context. Routledge (London): 343-390.

Pissart, A., Harmond, D. \& Krook, L., 1997. L'évolution de la Meuse de Toul à Maastricht depuis le Miocène: correlations chronologiques et traces des captures de la Meuse lorraine d'après les minéreux denses. Géographie physique et quaternaire 51:267-284.

Pike, K. \& Godwin, H., 1953. The interglacial at Clacton-on-Sea. Quarterly Journal of the Geological Society of London 108: 1122 . 
Porter, S.C., An, Z. \& Zheng, H., 1992. Cyclic Quaternary alluviation and terracing in a nonglaciated drainage basin on the north flank of the Qinling Shan, central China. Quaternary Research 38: 157-169.

Preece, R.C., 1995. Mollusca from interglacial sediments at three critical sites in the Lower Thames. In: Bridgland, D.R., Allen, P. \& Haggart, B.A. (Eds): The Quaternary of the lower reaches of the Thames. Field Guide, Quaternary Research Association (Durham): 55-60.

Preece, R.C., 1999. Mollusca from the Last interglacial fluvial deposits at Trafalgar Square, London. Journal of Quaternary Science 14: 77-89.

Preece, R.C. \& Parfitt, S.A., 2000. The Cromer Forest Bed Formation: new thoughts on an old problem. In: Lewis, S.G., Whiteman, C.A. \& Preece, R.C. (Eds): The Quaternary of Norfolk and Suffolk. Field Guide, Quaternary Research Association (London): 1-27.

Rabeder, G., 1974. Die Kleinsäugerfauna des Jungpliozäns von Stranzendorf. Mitteilung Quartärkommission Österreichische Akademie Wissenschaften 1: 137-139.

Rabeder, G., 1981. Die Arvicoliden (Rodentia, Mammalia) aus dem Pliozän und dem älteren Pleistozän von Niederösterreich. Beiträge Paläontologie Österreich 8: 1-337.

Raposo, L., 1993. L'Acheuléen dans la vallée du Tage, au Portugal. Publ. du CERP, 4, Université des Sciences et Technologies de Lille.

Raposo, L.\& Santonja, M., 1995. The earliest occupation of Europe: the Iberian Penisula. In: Roebroeks, W. \& Van Kolfschoten, T. (Eds): The Earliest Occupation of Europe. University of Leiden, The Netherlands: 7-25.

Richards, D.A. \& Smart, P.L., 1991. Potassium-argon and argonargon dating. In: Smart, P.L. \& Frances, P.D. (Eds): Quaternary Dating Methods - A User's Guide. Quaternary Research Association Technical Guide No.4. Quaternary Research Association (Cambridge): 37-44.

Rodbell, D. T. \& Forman, S.L., In press. Loess and paleosol stratigraphy, magnetic susceptibility, and thermoluminescence age estimates of Mississippi Valley loess in western Tennessee: The Geological Society of America Bulletin.

Roebroeks, W. \& Van Kolfschoten, T. (Eds), 1995. The Earliest Occupation of Europe. University of Leiden, The Netherlands: 332 pp.

Rohde, P., 1989. Elf pleistozäne Sand-Kies-Terrassen der Weser: Erläuterung eines Gliederungsschemas für das obere Weser-Tal. Eiszeitalter und Gegenwart 39: 24-56.

Ruegg, G.H.J., 1994. Alluvial architecture of the Quaternary Rhine-Meuse river system in the Netherlands. Geologie en Mijnbouw 72: 321-330.

Said, R., 1993. The River Nile. Geology, Hydrology and Utilization. Pergamon Press (Oxford): 320 pp.

Salama, R., 1999. The evolution of the River Nile in Sudan. Book of Abstracts, XV INQUA Congress, Durban, South Africa: 155156.

Saryca, N., 2000. The Plio-Pleistocene age of the Büyük Menderes and Gediz grabens and their tectonic significance on N-S extensional tectonics in West Anatolia: mammalian evidence from the continental deposits. Geological Journal 35: 1-24.

Sanver, M., 1968. A palaeomagnetic study of Quaternary volcanic rocks from Turkey. Physics of the Earth and Planetary Interiors 1: 403-421.

Sandford, K.S., 1934. Paleolthic Man and the Nile Valley in Upper and Middle Egypt. Chicago: Chicago University Press, Oriental Publication 3: 1-131.

Santonja, M., Moissenet, E. \& Pérez Gonzales, A., 1992. Cuesta de la Bajada (Teruel). Nuevo sítio Paleolítico inferior. Boletin del
Seminario de Estudios de Arte y Arqueologia 58: 25-45.

Santonja, M. \& Pérez Gonzales, A., 1984. Las industrias paleolíticas de La Maya en su âmbito regional. Excavaciones Arqueológicas en Espanã, 135. Ministerio de Cultura, Madrid.

Santonja, M. \& Villa, P., 1990. The Lower Paleolithic of Spain and Portugal. Journal of World Prehistory 4: 45-94.

Saucier, R.T., 1996. Geomorphology and Quaternary geologic history of the Lower Mississippi Valley. U.S. Army Corps of Engineers (Vicksburg): $364 \mathrm{pp}$.

Schmidt, U., 1996. Sedimente und Fossiliendes Jungpleistozäns im nördlichen Ruanda. Stuttgart: Zentralblatt Geologie Paläontologie Teil I: 849-857.

Schmidt, U. \& Neuffer, Fr.-O., 1995. Zr Hydrogeographie Ruandas. Die pleistozänen Sedimente von Massangano. Stuttgart: Zentralblatt Geologie Paläontologie Teil I: 487-494.

Schreve, D.C., 2001. Differentiation of the British late Middle Pleistocene interglacials: the evidence from mammalian biostratigraphy. Quaternary Science Reviews 20: 1693-1705.

Schwarcz, H.P., Grün, R., Latham, A.G., Mania, D. \& Brunnacker, K., 1988. The Bilzingsleben Archaeological Site: New Dating Evidence. Archaeometry 30: 5-17.

Semaw, S., Renne, P. Harris, J.W.K., Feibel, C.S. Bernor, R.L., Fesseha, N. \& Mowbray, K., 1997. 2.5 million-year-old stone tools from Gona, Ethiopia. Nature 385: 333-336.

Shackleton, N.J., Berger, A. \& Peltier, W.R., 1990. An Alternative Astronomical Calibration of the Lower Pleistocene Timescale Based on ODP Site 677. Transactions of the Royal Society of Edinburgh 81:252-261.

Sher, A. V., Giterman, R. Y., Zazhigin, V. S. \& Kiselev, S. V., 1977. New data on the Late Cenozoic deposits of the Kolyma Lowland. Akademie Nauk SSSR Izvesti Seriya Geolozh 5: 69-83. (In Russian)

Smart, P.L., 1991. General principles. In: Smart, P.L. \& Francis, P.D. (Eds): Quaternary Dating Methods, a User's Guide. Technical Guide 4, Quaternary Research Association (Cambridge): 1-15.

Stathopolos, L. \& Hare, P.E., 1993. Bleach removes labile amino acids from deep sea planktonic foraminifera. Journal of Foraminiferal Research 23: 102-107.

Sugai, T., 1993. River terrace development by concurrent fluvial processes and climatic changes. Geomorphology 6: 243-252.

Sykes G. A., Collins M. J. \& Walton D. I., 1995. The significance of a geochemically isolated (intracrystalline) organic fraction within biominerals. Organic Geochemistry 23: 1059-1106.

Thomas, G.N., 2001. Late Middle Pleistocene pollen biostratigraphy in Britain: pitfalls and possibilities in the separation of interglacial sequences. Quaternary Science Reviews 20: 1621-1630.

Tuffreau, A. \& Antoine, P., 1996. The earliest occupation of Europe: Continental Northwestern Europe. In: Roebroeks, W. and Van Kolfschoten, T. (Eds): The Earliest Occupation of Europe. University of Leiden, The Netherlands: 147-163.

Tyràcek, J., 1983. River terraces - important paleoclimatic indicator. In: Billards, O., Conchon, O. \& Shotton, F.W. (eds) Quaternary glaciations in the Northern Hemisphere. IGCP Project 731-24. Report No. 9, Unesco International Geological Correlation Programme, Paris: 34-41.

Tyràcek, J., 1987. Terraces of the Euphrates River. Sbornik geologickych ved 18: 185-202.

Tyràcek, J., 1995. Stratigraphy of the Ohøe River terraces in the Most Basin. Sbornik geologickych ved 22: 1-157.

Tyràcek, J., 2001a. Upper Cenozoic fluvial history in the Bohemian Massif. Quaternary International 79: 37-53.

Tyràcek, J., 2001b. Quaternary of the Milnik Area: Excursion Guide. Czech Geological Survey, Prague, ISBN 80-7075-518-0, $17 \mathrm{pp}$. 
Tzedakis, P.C., Andrieu, V., de Beaulieu, J.-L., Crowhurst, S., Follieri, M., Hooghiemstra, H., Magri, D., Reille, M., Sadori, L., Shackleton, N.J. \& Wijmstra, T.A., 1997. Comparison of terrestrial and marine records of changing climate of the last 500,000 years. Earth and Planetary Science Letters 150: 171-176.

Ünay, E., Emre, Ö., Erkal, T. \& Keçer, M., 2001. The rodent fauna from the Adapazary pull-apart basin (NW Anatolia): its bearing on the age of the North Anatolian fault. Geodinamica Acta 14: 169-175.

Urban, B., 1995. Palynological evidence of younger Middle Pleistocene interglacials (Holsteinian, Reinsdorf and Schöningen) in the Schöningen open cast lignite mine (eastern Lower Saxony, Germany). Mededelingen Rijks Geologische Dienst 52: 175185.

Van den Berg, M.W., 1994. Neo-tectonics in the Roer Valley Rift System. Style and rate of crustal deformation inferred from syntectonic sedimentation. Geologie en Mijnbouw 73: 143-156.

Van den Berg, M.W., 1996. Fluvial sequences of the Maas: a $10 \mathrm{Ma}$ record of neotectonics and climate change at various time-scales. Thesis, University of Wageningen: $181 \mathrm{pp}$.

Vandenberghe, J., 1995. Timescales, climate and river development. Quaternary Science Reviews 14: 631-638.

Van den Boogard, C., Van den Boogard, P. \& Schmincke, H.-U., 1989. Quartärgeologisch-tephrostratigraphische Neuaufnahme und Interpretation des Pleistozänprofils Kärlich, F.R.G. Eiszeitalter und Gegenwart 39: 62-86.

Van Kolfschoten, T. \& Turner, E., 1996. Early Middle Pleistocene mammalian faunas from Kärlich and Miesenheim $\mathrm{I}$ and their biostratigraphical implications. In: Turner, C. (ed.): The early Middle Pleistocene in Europe. Balkema (Rotterdam): 21 1-253.

Van Liere, W.J., 1960/1. Observations on the Quaternary of Syria. Berichten van de Rijksdienst voor het Oudheidkundig Bodemonderzoek 10 \& 11: 7-69.

Veldkamp, A., 1992. A 3-D model of Quaternary terrace development, simulations of terrace stratigraphy and valley asymmetry: a case study for the Allier terraces (Limagne, France). Earth Surface Processes \& Landforms 17: 487-500.

Veldkamp, A. \& Kroonenberg, S.B., 1993. The Late Quaternary terrace chronology of the Allier. Geologie en Mijnbouw 72: 179192.

Veldkamp, A. \& Van den Berg, M.W., 1993. Three-dimensional modelling of Quaternary fluvial dynamics in a climo-tectonic depenent system. A case study of the Maas record (Maastricht, The Netherlands). Global and Planetary Change 8: 203-218.

Veldkamp, A. \& Van Dijke, J.J., 1998. Modelling long-term erosion and sedimentation processes in fluvial systems: A case study for the Allier/Loire system. In: Benito, G., Baker, V.R. \& Gregory, K.J. (Eds): Palaeohydrology and environmental change. Wiley (Chichester): 53-66.

Veldkamp, A. \& Van Dijke, J.J., 2000. Simulating internal and external controls on fluvial terrace stratigraphy: a qualitative comparison with the Maas record. Geomorphology 33: 225-236.

Velegrakis, A.F., Dix, J.K. \& Collins, M.B., 1999. Late Quaternary evolution of the upper reaches of the Solent River, Southern
England, based upon marine geophysical evidence. Journal of the Geological Society 156: 73-87.

Veklich, M.F., Matviishina, Z.N. \& Ivchenko, A.S., 1993. Stratigraphical schemes of the Pliocene and Pleistocene sediments of Ukraine (in Russian), Naukova Dumka, Kiev: 76 pp.

Wayland, E.J., 1934. Rifts, rivers, rains, and early man in Uganda. Royal Anthropological Institute Journal 6: 64.

Wendorf, F. \& Schild, R., 1976. Prehistory of the Nile Valley. Academic Press (New York): 404 pp.

West, R.G., 1956. The Quaternary deposits at Hoxne, Suffolk. Philosophical Transactions of the Royal Society of London B239: 265-356.

Westaway, R., Maddy, D. \& Bridgland, D., 2002. Flow in the lower continental crust as a mechanism for the Quaternary uplift of south-east England: constraints from the Thames terrace record. Quaternary Science Reviews 21: 559-603.

Winguth, C., Wong, H.K., Panin, N., Dinu, C., Georgescu, P., Ungureanu, G., Krugliakov, V.V. \& Podshuveit, V., 2000. Upper Quaternary water level history and sedimentation in the northwestern Black Sea. Marine Geology 167: 127-146.

Wymer, J.J., 1968. Lower Palaeolithic Archaeology in Britain, as represented by the Thames Valley. John Baker (London): $429 \mathrm{pp}$.

Wymer, J.J., 1988. Palaeolithic archaeology and the British Quaternary sequence. Quaternary Science Reviews 7: 79-98.

Wymer, J.J., 1999. The Lower Palaeolithic occupation on Britain. Wessex Archaeology and English Heritage (Salisbury): 234 pp + 2nd volume of maps.

Yamskikh, A.F., 1996. Late Quaternary intra-continental river palaeohydrology and polycyclic terrace formation: the example of south Siberian river valleys. In: Branson, J., Brown, A.G. \& Gregory, K.J. (Eds): Global Continental Changes: the Context of Palaeohydrology. Geological Society Special Publication No. 115: 181-190.

Yim, W.W., 1994. Offshore Quaternary sediments and their engineering significance in Hong Kong. Engineering Geology 37: 31-50.

Zagwijn, W.H., 1985. An outline of the Quaternary stratigraphy of The Netherlands. Geologie en Mijnbouw 64: 17-24.

Záruba, Q., 1942. Podélny profil Vltavskymi terasami mezi Kamykem a Veltrusy. Rozpravy Ceské Akademie Ved, trída II, 52, 9, 1-39.

Zeman, A., 1982. The main terrace of the Morava River and its relationship to loess sections. IGCP Project 73/1/24 - Quaternary Glaciations in the Northern Hemisphere, Rep. No. 7: 253-256.

Zöller, L., Oches, E.A. \& McCoy, W.D., 1994. Towards a revised chronostratigraphy of loess in Austria with respect to key sections in the Czech Republic and Hungary. Quaternary Geochronology 13: 465-472.

Zuchiewicz W., 1992. Pozycja stratygraficzna tarasow Dunajca w Karpatach Zachodnich (English summary). Przeglad Geologiczny (Warszawa) 40 (7): 436-445.

Zuchiewicz W. \& Butrym J., 1990. Stratigraphy of Quaternary deposits of Roznów foothills, Polish West Carpathians. Studia Geomorphologica Carpatho-Balcanica (Kraków) 24: 33-48. 